\title{
An Investigation on the Ecology of Triatoma vitticeps (Stal, 1859) and its Possible Role in the Transmission of Trypanosoma cruzi, in the Locality of Triunfo, Santa Maria Madalena Municipal District, State of Rio de Janeiro, Brazil
}

\author{
Teresa Cristina M Gonçalves/ ${ }^{+}$, Edson de Oliveira*, Lidiamara S Dias*, \\ Magaly D Almeida**, Wagner O Nogueira***, \\ Fernando Dias de Avila Pires $* * * *$
}

Núcleo de Morfologia, Anatomia Interna e Ultraestrutura de Artrópodos Vetores/Laboratório de Transmissores de

Leishmaniose e Oncocercose *Laboratório Nacional e Internacional de Referência em Taxonomia de

Triatomíneos **Coleção Entomológica, Departamento de Entomologia ****Departamento de Medicina Tropical, Instituto Oswaldo Cruz, Av. Brasil 4365, 21045-900 Rio de Janeiro, RJ, Brasil ***Fundação Nacional de Saúde/

COORRJ, Caixa Postal 1530, 20081-060 Rio de Janeiro, RJ, Brasil

From January 1989 to April 1995, 465 specimens of Triatoma vitticeps were collected in the locality of Triunfo, 2nd District of Santa Maria Madalena municipal district, State of Rio de Janeiro. The bugs were found indoors by local residents with predominance of adults. The flight activity was high in hot months when the incidence in the domicile also increased. Two hundred and two bugs (111 alive and 91 dead) were examined for Trypanosoma cruzi infection. This was detected in 31 of the dead bugs (34\%) and $88(79 \%)$ of the live bugs examined. With a view to investigate the possible vertebrate hosts of the T. cruzi isolates, the blood of 122 mammals was examined through Giemsa-stained smears, hemocultures and xenodiagnosis. T. cruzi was detected in three specimens of Didelphis marsupialis and T. (M.) theileri was detected in one specimen of Bos taurus. The parasites were isolated from triatomine feces, xenoculture and hemoculture. No evidence of human infection was detected in 58 inhabitants examined, as evaluated by indirect imunofluorescence technique using T. cruzi epimastigotes as antigens. These results show that $\mathrm{T}$. vitticeps is still a sylvatic species although nymphs have been found inside the domicile. Thus, an epidemiological vigilance is necessary to know the behaviour of this species following the continuous modifications promoted by the presence of man.

Key words: Triatoma vitticeps - ecology - Trypanosoma cruzi - State of Rio de Janeiro - Brazil

Triatoma vitticeps has been found in the states of Bahia, Espírito Santo, Minas Gerais and Rio de Janeiro (Silveira et al. 1984, Carneiro et al. 1985, Corrêa 1986).

This species was found colonizing the domicile for the first time in Espírito Santo (Santos et al. 1969b). Lent and Jurberg (1978) confirmed its colonization in Espírito Santo, Minas Gerais and

\footnotetext{
This work was supported by Programa de Apoio à Pesquisa Estratégica em Saúde (Papes, Fiocruz), Conselho Nacional de Desenvolvimento Científico e Tecnológico (CNPq), Fundação de Amparo a Pesquisa do Rio de Janeiro (Faperj) and Bird/FNS/Fiocruz contract number $027 / 93$.

${ }^{+}$Corresponding author. Fax: +55-21-290.9339. E-mail: tcmonte@gene.dbbm.fiocruz.br

Received 12 January 1998

Accepted 25 June 1998
}

Rio de Janeiro. In Espírito Santo, Silveira et al. (1983) and Sessa and Carias (1986) registered the colonization in seven and in one municipal districts, respectively. Dias et al. (1989) emphasized the high dispersion in this state, reporting signs of colonization in some districts. Ferreira et al. (1986) described the occurrence of T. vitticeps in the State of Rio de Janeiro, from the city of Rio de Janeiro to the north of the state.

The present study was carried out in the locality of Triunfo, 2nd District of Santa Maria Madalena municipal district, which has the higher incidence of the triatomine infected with T. cruzilike (Ferreira et al. 1986). The aim of the ecology study of $T$. vitticeps in natural habitat and the investigation of the infection in domestic, synanthropic and wild triatomines and mammals, is to know the actual situation of this area and to alert to the possible risk of colonization contribuing to programs of vigilance and control. 


\section{MATERIALS AND METHODS}

Santa Maria Madalena municipal district is situated at an altitude of $620 \mathrm{~m}$, latitude $21^{\circ} 37^{\prime} \mathrm{S}$ and longitude $42^{\circ} 05^{\prime} \mathrm{W}$, in the State of Rio de Janeiro, Brazil. Triunfo, the 2nd District of Santa Maria Madalena is situated in the south, latitude $22^{\circ} 02^{\prime} 52^{\prime \prime} \mathrm{S}$ and longitude $41^{\circ} 56^{\prime} 32^{\prime \prime} \mathrm{W}$ (Fig. 1), at the bottom of a mountain, cut by water courses flowing into the Macabu River. The vegetation of the region is typical of an open perennial hygrophyle forest, partly modified by the formation of fields for pasture and banana cultivation.

The triatomines were captured in five areas: area A - $250 \mathrm{~m}$ altitude, $3.5 \mathrm{~km}$ from the village, profoundly modified by deforestation for banana cultivation; area B - $130 \mathrm{~m}$ altitude, $4 \mathrm{~km}$ from the village, in a valley with a preserved vegetation (secondary forest). These areas are $2 \mathrm{~km}$ far from each other, separated by a mainly rocky geographical barrier (mountain) with altitude $400 \mathrm{~m}$ to 900 $\mathrm{m}$. The area C- $40 \mathrm{~m}$ altitude, is the village itself, greatly modified by the formation of fields for pasture. The areas D and E - greatly preserved, $10 \mathrm{~km}$ and $12 \mathrm{~km}$, from the area $\mathrm{C}$, respectively (Fig. 1).

Monthly, from January 1989 to April 1995, 44 trips of one day were made just to collect the triatomines captured by the population, and 22 trips of one week were made to investigate: (1) the natural ecotopes of the bugs (birds nest, hollow trees and cracks and barks, holes on the ground, railing, bromelia, etc.), and the peridomicile, using in all situations a pyrethrum solution to dislodge the bugs; (2) previously demarcated areas, using the methodology of transect strip; (3) the attraction of the bugs to light-traps; (4) the climatic gauging. The trips were also made to capture the mammals using iron traps $(22 \times 22 \times 45 \mathrm{~cm}$ and $10 \times 14 \times 31 \mathrm{~cm})$, which were distributed in the peridomestic and sylvatic environments of areas A, B and C.

From January 1989 to April 1990, two lighttraps with electric and gas light were set eight times from 8 p.m. to 10 p.m. with climate gauging at the end of each hour. From June 1993 to April 1995 only electric light-traps were set 14 times from dusk to dawn with climate gauging at the end. The traps were placed always close to the house, and preferably, in the new moon period.

The triatomines collected were identified according to the place of capture, sex and if they were alive or dead.

Data on temperature during 1989/1995 were supplied by National Meteorology Institute.

In the laboratory, the triatomines were immersed in $80 \%$ ethyl alcohol solution and later dissected under sterile conditions. Their guts were ground in saline with fluorocytosine and then distributed into test tubes containing blood-agar
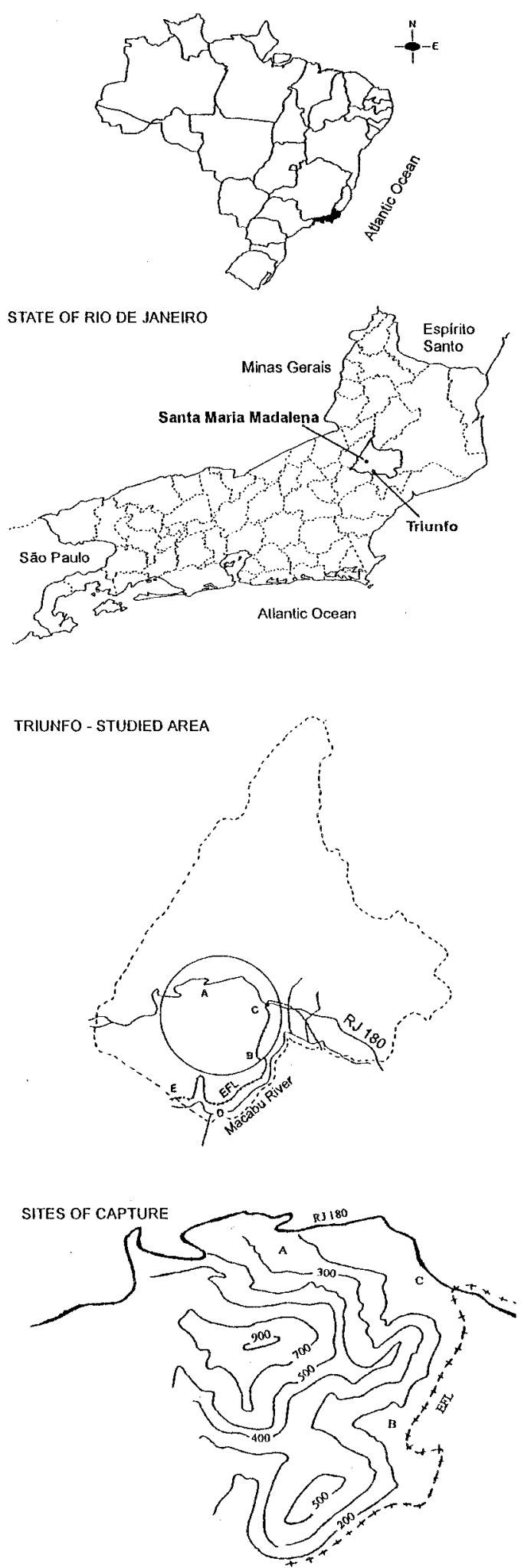

Fig. 1: studied area and sites of capture in Triunfo, Santa Maria Madalena municipal district, State of Rio de Janeiro, Brazil. 
medium (NNN) with a LIT overlay. The positive cultures were cryopreserved in liquid nitrogen for subsequent molecular and biochemical characterization (Gonçalves et al. 1996).

To verify the possibility of $T$. cruzi infection, 18-20 g swiss mice were intraperitoneally (IP) inoculated with $0.1 \mathrm{ml}$ of gut content of the bugs examined. The deteccion of the flagellates was verified by microscopic exam.

To identify the possible reservoir hosts of $T$. cruzi, marsupials, rodents, edentates, equines, bovines and canines, trapped in peridomestic and sylvatic environments, were examined through Giemsa-stained blood smears, by hemoculture and xenodiagnosis. Afterwards, the animals were cool marked with a special paste with $20 \%$ of sodium hydroxide (NaOH) (Paste R-5) in order to identified an animal captured twice. The hemocultures were examined on day $11,30,45$ and 60 , according to Fernandes et al. (1990).

The total of 40 specimens of Panstrongylus megistus, Rhodnius prolixus, T. infestans and $T$. vitticeps (4th instar nymphs), unfed during a two weeks period, were used for xenodiagnosis. These insects were obtained from the insectary of the Laboratório Nacional e Internacional de Referência em Taxonomia de Triatomíneos, Instituto Oswaldo Cruz. Unfed or little engorged bugs were discarded. Results of xenodiagnosis, on the 45th day after feeding, were confirmed by xenoculture of the intestinal contents of the bugs, following the same methodology used for hemoculture.

The occurrence of $T$. cruzi human infection was assayed by the sorologic test (indirect imunofluorescence reaction) in inhabitants of Triunfo and Amorosas, Conceição de Macabu municipal district boundary with the area under investigation. The persons examined were those presenting evidences of bite by bugs or living in houses where bugs were found.

\section{RESULTS}

From 465 specimens, 455 (98\%) were found in indoors by local residents, $9(2 \%)$ were caught in light-traps placed near houses and $1(0.2 \%)$ was found in the domiciliary area. Of the bugs found indoors, 294 (65\%) were females, $156(34 \%)$ were males and $15(3 \%)$ were nymphs including all instars. All specimens were identified as T. vitticeps and no other species was found. In spite of the difference between the number of triatomines captured mainly in areas A and B, in both areas and all months of the year the number of females was markedly higher than the males. In area $\mathrm{C}$, where the number of houses was higher, the triatomines were captured only in those at the boundary close to the forest. In areas D and E, the distance from the village hampered the contact with the inhabitants. The search in the bug's natural habitats were always negative.

The number of bugs captured per month showed a pronounced annual cycle correlated with average temperature, with a maximum in January and a minimum in June. During this time the number of females was always higher than the males, although in the months of January, May, June, July, August, September, October and December the incidence of females was ${ }^{3} 50 \%$ than the males. The nymphs were found in January, March, April, May, November and December (Fig. 2).

Among the 22 houses included in the survey, only 2 , one in area $\mathrm{A}$ and the other in area $\mathrm{B}$, were invaded with high frequency. The highest annual incidence of triatomines occurred in 1990 (63 and 45 bugs) in both houses and the lowest in 1994 (5 bugs) and 1995 (13 bugs), in houses of areas A and $\mathrm{B}$, respectively. The highest nymph incidence occurred in 1991 and 1992 (Fig. 3).

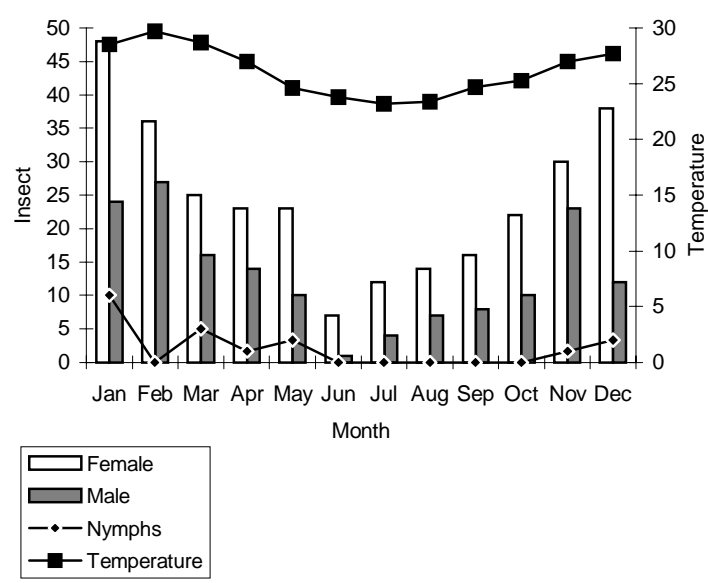

Fig. 2: mean monthly temperature and distribution of Triatoma vitticeps, captured in Triunfo, Santa Maria Madalena municipal district, State of Rio de Janeiro, during 1989/1995.

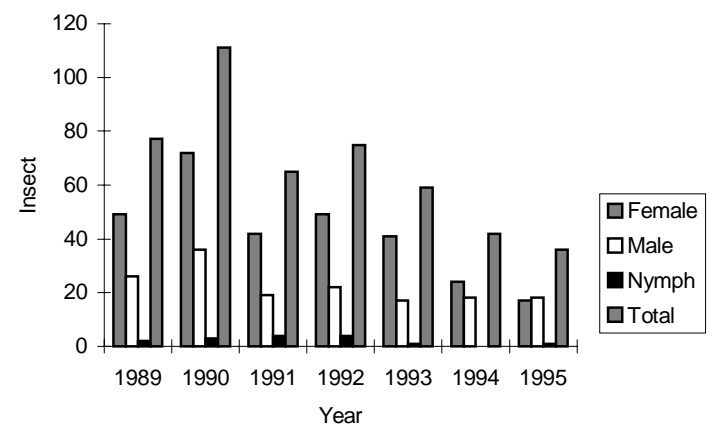

Fig. 3: annual distribution of Triatoma vitticeps, captured in Triunfo, Santa Maria Madalena municipal district, State of Rio de Janeiro, during 1989/1995. 
The natural ecotopes examined included aproximately 50 birds' nests, 20 marsupial nests, 200 armadillo holes, 50 hollow trees and cracks and barks, 5 railings and 15 bomelias, all of them were negative for triatomines.

The nine bugs captured in light-traps were taken on nights with mean temperature between $24.5^{\circ} \mathrm{C}$ and $30^{\circ} \mathrm{C}$ with the occurrence of gust of wind. The highest incidences (five insects) occurred in February 1994 and the others in January 1989, March 1989, August 1993 and November 1994.

From the total specimens captured, 202 (111 alive and 91 dead) were examined for $T$. cruzi infection. T. cruzi was detected in $88(79 \%)$ of the live bugs and 31 (34\%) of the dead bugs examined. Rates of infection in adults were similar for males (59\%) and females (62\%) and did not differ significantly between areas. One out of nine nymphs (11\%) examined was positive for $T$. cruzi (Tables I, II). Some females were fertile but, unfortunately, this number was not quantified.

In 68 isolates from the bugs, the flagellates were identified as T. cruzi either regarding the morphology of the trypomastigotes (metacyclics) seen in their intestinal content or of the bloodstream trypomastigotes seen in mice experimentally inoculated with these forms. Fifty axenic cultures of these flagellates were obtained and were cryopreserved in liquid nitrogen.

The investigation of the natural reservoir was performed in 122 mammals: 22 domestic animals ( 3 cows, 8 horses, 1 donkey, 1 mule and 9 dogs); 16 black rats (Rattus rattus) 41 native rodents including 5 Holochilus brasiliensis, 1 Oxymycterus quaestor, 2 Oxymycterus sp., 1 Akodon sp. and 32 unindentified; 32 marsupials including 12 Didelphis marsupialis, 4 Philander opossum and 1 Metachirus nudicaudatus and 11 armadillos including 6 Dasypus novemcinctus and 4 D. septemcinctus. T. cruzi was detected only in 3 D. marsupialis $(25 \%)$ and T. (M.) theileri was detected in 1 cow.
TABLE II

Incidence and percentual of dead Triatoma vitticeps, infected by Trypanosoma cruzi flagellates

\begin{tabular}{lcrcc}
\hline Area & Female & $\%$ & Male & $\%$ \\
\hline A & 8 & 9 & 7 & 8 \\
B & 9 & 10 & 4 & 4 \\
C & 0 & 0 & 3 & 3 \\
D & 0 & 0 & 0 & 0 \\
E & 0 & 0 & 0 & 0 \\
\hline
\end{tabular}

All mammals were examined through Giemsastained blood smear, with negative results. Fifty two were submitted to xenodiagnosis, 20 to hemoculture and 35 to both xenodiagnosis and hemoculture. One marsupial male from area A had the xenodiagnosis positive to T. cruzi. Among the triatomines used for xenodiagnosis in the captured mammals, the specimens of T. vitticeps, $P$. megistus and $R$. prolixus which had fed in the marsupial were positive to $T$. cruzi on the 45th day for the first one and 53th day for the last two. Two marsupial males from area B showed hemoculture positive on the 9th and 14th day, but, unfortunately, the parasite isolation was unsuccessful. One cow had the hemoculture positive to T. (M.) theileri.

Sorologic tests (indirect imunofluorescence), were negative for all 58 residents tested ( 35 from Triunfo and 23 from Amorosas) in whose house bugs had been found or who reported having been bitten by triatomines.

\section{DISCUSSION}

T. vitticeps may be considered a sylvatic species by the low prevalence of human infection (Santos et al. 1969a,c, Pinto et al. 1969, 1986, Barros et al. 1975, Peçanha et al. 1983, Silveira et al. 1983, Dias et al. 1989) and the high rates of infection by $T$. cruzi observed only in adults bugs (Santos et al. 1969b, Silveira et al. 1983, Ferreira et al. 1986, Sessa \& Carias 1986, Dias et al. 1989),

TABLE I

Triatoma vitticeps captured according to the area, developmental stage and infection by Trypanosoma cruzi flagellates

\begin{tabular}{|c|c|c|c|c|c|c|c|c|c|}
\hline \multirow[t]{2}{*}{ Area } & \multicolumn{3}{|c|}{ Female } & \multicolumn{3}{|c|}{ Male } & \multicolumn{3}{|c|}{ Nymphs } \\
\hline & + & - & N/R & + & - & N/R & + & - & N/R \\
\hline A & 49 & 29 & 78 & 21 & 16 & 42 & 1 & 7 & 4 \\
\hline B & 26 & 17 & 77 & 15 & 11 & 41 & 0 & 0 & 1 \\
\hline $\mathrm{C}$ & 2 & 2 & 10 & 3 & 0 & 7 & 0 & 1 & 1 \\
\hline $\mathrm{D}$ & 1 & 0 & 2 & 0 & 0 & 0 & 0 & 0 & 0 \\
\hline $\mathrm{E}$ & 1 & 0 & 0 & 0 & 0 & 0 & 0 & 0 & 0 \\
\hline Total & 79 & 48 & 167 & 39 & 27 & 90 & 1 & 8 & 6 \\
\hline
\end{tabular}

N/R: no results 
evidencing that the parasite has been acquired outside the houses. However, it is begining to colonize in some localities (Sessa \& Carias 1986, Dias et al. 1989, Santos et al. 1969b, Silveira et al. 1983), suggesting a wide ecological valence which was previously low (Forattini et al. 1979).

The results of the present work show a great difference in the number of insects trappeded in areas A and B of the locality of Triunfo, which seems to be related with the preservation of the second area, since both were isolated from each other and from area $\mathrm{C}$.

From the specimens trapped in the houses, $65 \%$ presented no intestinal content and some were without internal structures, showing their difficulty to find hosts to feed on and consequently a bad nutricional conditions which may be influencing dispersive flight (Schofield 1985).

The high incidence of $T$. vitticeps in domicile during hot months is in agreement with the previous observation of the high temperature correlation and the increased avidity of the insect to seek blood meal (Zeledón \& Rabinovich 1981), which is responsible for the starting point and the duration of the flight (Schofield et al. 1992). However, it is worth mentioning that no correlation has been found between high temperature and incidence of triatomines, based on data obtained by the National Meteorology Institute, in the 1989/1995 period.

According to declarations of inhabitants, the incidence of triatomines inside houses was associated with gust of warm wind, suggesting that the flight might have enabled the triatomines to reach long distances.

In this study the number of females trapped (63\%) was higher than the males (34\%), both in areas $\mathrm{A}$ and $\mathrm{B}$, in aggreement with the findings of Sessa and Carias (1986) and Schofield et al. (1991) in this case related to $T$. infestans, showing that females migrate more than males. This can be due to a higher necessity of blood meal by females (Dias et al. 1989, Gonçalves et al. 1991).

The discovery of some nymphs of $T$. vitticeps in the domicile in Triunfo, cannot be an evidence of its domiciliation, because first of all not all the developmental stages (including eggs) were found together in the same house.

The light-trap set at dusk and down were not efficient in trapping triatomines, contradicting the observations of Bertram (1971) and Ekkens (1981) apud Zeledón (1983), which displayed a higher attraction of these insects to light-traps used in certain hours of the night. Tonn et al. (1978) had results related to kerosene, white and black electric lights, with $R$. prolixus, in opposition to Zárate et al. (1980) who did not observe the attraction to $T$. barberi, by black light set close to the house. In the present work, although gas and white electric lights trapped $T$. vitticeps, they did so in low numbers.

In Triunfo, despite the low socio-economic status of the population the majority of the houses were built with brick and have skylight rather than a ceiling light, which makes them similar to a big light-trap, faciliting the incidence of $T$. vitticeps, but not the establishment of colonies.

The infection rate $(59.31 \%)$ of adult triatomines from Triunfo by $T$. cruzi confirms the results obtained by Silveira et al. (1983) and Sessa and Carias (1986) in Espírito Santo. However, in the present study it was registered for the first time one 5th instar nymph infected with T. cruzi in the bedroom, possibly acquired outside the domicile.

In the present paper, one marsupial has the xenodiagnosis positive to $T$. cruzi using $T$. vitticeps, $P$. megistus and $R$. prolixus, but not to T. infestans evidencing that sylvatic species and others, showing current tendency to domiciliation, are more susceptible to the $T$. cruzi infections than the domiciliate ones. The mutations suffered by the domiciliated species due to the gradual adaptation to the domicile, also make the adaptation of the parasite difficult (Perlowagora-Szumlewicz \& Müller 1982, Moreira \& Perlowagora-Szumlewicz 1997).

The finding of three marsupials positive between the 122 mammals examined and the failure to detect infection in $R$. rattus and armadillos, importants reservoirs, may be justified by the inefficiency of xenodiagnosis and hemoculture (Fernandes et al. 1990, Perlowagora-Szumlewicz et al. 1990).

The number of infected sylvatic bugs found in houses and the absence of human trypanosomiasis may be explained by its low agressivity and slow defecation (Diotaiuti et al. 1987, Gonçalves et al. 1988). This fact should alert medical personnel do acute Chagas' disease as possible diagnosis in febrile cases, and householder should be warned to protect foodstuff from contamination by these insects.

The epidemiologic vigilance and the working conciousness of the population will be necessary to render difficult the establishment of domestic colonies of the insect.

Complementary studies about food sources of T. vitticeps (Gonçalves et al. 1991), and the biochemistry characterization of the parasite isolates (Gonçalves et al. 1996) will allow researchers to identify the possible natural reservoirs and to evaluate the degree of parasite circulation in the area, contributing for a better knowledge of the local epidemiological situation. 


\section{ACKNOWLEDGEMENTS}

To Dr José Rodrigues Coura and to Mr Júlio Cesar Miguel for the support and the serological assays. To Drs Josimar Ribeiro de Almeida and Maria Auxiliadora de Sousa for the valuable comments on the manuscript.

\section{REFERENCES}

Barros GC, Mayrink W, Salgado AA, Barros RCG, Sessa PA 1975. Contribuição para o conhecimento da doença de Chagas autóctone no Estado do Espírito Santo. Rev Inst Med Trop São Paulo 17: 319-329.

Carneiro M, Loiola CCP, Lima SG, Diotaiuti L 1985. Presença do Triatoma vitticeps em ecótopos artificiais no Estado de Minas Gerais, 1985, VE-40. An. XII Reunião Anual sobre Pesquisa Básica em Doença de Chagas, Caxambu.

Corrêa RR 1986. Informe sobre a doença de Chagas no Brasil e em especial no Estado de São Paulo. Rev Bras Malariol D Trop 20: 39-81.

Dias JCP, Feitosa VR, Ferraz Filho AN, Rodrigues VLC, Alencar SA de, Sessa PA 1989. Fonte alimentar e potencial vetorial de Triatoma vitticeps (Stal, 1859) com relação à doença de Chagas humana no Estado do Espírito Santo, Brasil (Hemiptera, Reduviidae). Mem Inst Oswaldo Cruz 84: 165-173.

Diotaiuti L, Bronfen E, Perilo MM, Machado GBN, Loiola CF 1987. Aspectos do comportamento do Triatoma vitticeps na transmissão da doença de Chagas. Rev Soc Bras Med Trop 20 (Supl.): 87.

Fernandes AJ, Chiari E, Chiari CA 1990. Diagnóstico de infecção pelo Trypanosoma cruzi em gambás, naturalmente infectados, pela reação de imunofluorescência indireta. Rev Inst Bras Med Trop 23: 157-161.

Ferreira E, Souza PA de, Fonseca Filho M da, Rocha I 1986. Nota sobre a distribuição geográfica do Triatoma vitticeps (Stal, 1859) (Hemiptera, Reduviidae) no Estado do Rio de Janeiro, Brasil. Rev Brasil Malariol D trop 38: 11-14.

Forattini OP, Ferreira OA, Rocha e Silva EO, Rabello EX 1979. Aspectos ecológicos da tripanosomíase americana. XV - Desenvolvimento, variação e permanência de Triatoma sordida, Panstrongylus megistus e Rhodnius neglectus em ecótopos artificiais. Rev Saúde públ São Paulo 13: 220-234.

Gonçalves TCM, Victório VMN, Jurberg J, Cunha V 1988. Biologia do Triatoma vitticeps (Stal, 1859) em condições de laboratório (Hemiptera: Reduviidae: Triatominae). I Ciclo evolutivo. Mem Inst Oswaldo Cruz 83: 519-523.

Gonçalves TCM, Almeida MD, Cunha RA 1991. Observações preliminares sobre a fonte alimentar de Triatoma vitticeps (Stal,1859) procedente de localidades do Estado do Rio de Janeiro. Rev Soc Brasil Med Trop 24 (Supl. II): 182.

Gonçalves TCM, Nogueira RS, Gomes SAO, Sousa MA 1996. Characterization of Trypanosoma cruzi-like isolates from Triatoma vitticeps (Stal,1859) captured in Santa Maria Madalena (Rio de Janeiro, Brazil). Mem Inst Oswaldo Cruz 91: 219

Lent H, Jurberg J 1978. Estudo comparativo da genitália externa masculina de seis espécies de Triatoma
Laporte, 1832 que mais freqüentemente habitam o domicílio humano no Brasil (Hemiptera: Reduviidae). Rev Brasil Biol 38: 931-944.

Moreira CJC, Perlowagora-Szumlewicz A 1997. Attempts to improve xenodiagnosis: Comparative test of sensibility using Rhodnius neglectus, Panstrongylus megistus, Triatoma vitticeps and Triatoma infestans in endemic areas of Brazil. Mem Inst Oswaldo Cruz 92: 91-96.

Peçanha PM, Sessa PA, Silva FJD, Pereira RS, Almeida IM 1983. Doença de Chagas - Apresentação de três casos autóctones do Estado do Espírito Santo, p. 33. XIX Congresso da Soc Bras Med Trop, Rio de Janeiro.

Perlowagora-Szumlewicz A, Müller CA 1982. Studies in search of a suitable experimental insect model for xenodiagnosis of hosts with Chagas' disease. 1Comparative xenodiagnosis with nine triatomine species of animals with acute infections by Trypanosoma cruzi. Mem Inst Oswlado Cruz 77: 37-53.

Perlowagora-Szumlewicz A, Müller CA, Moreira CJC 1990. Studies in search of a suitable experimental insect model for xenodiagnosis of hosts with Chagas' disease. 4 - The reflection of parasites stock in the responsiveness of different vector species to chronic infection with different Trypanosoma cruzi stocks. Rev Saúde Públ São Paulo 24: 165-177.

Pinto AFS, Santos UM, Murad V, Lima FEP, Zaganelli FL, Almeida AZ 1969. Doença de Chagas no Estado do Espírito Santo. V - Primeiro caso de Chagas diagnosticado no Município de Alfredo Chaves, E.S. Rev Soc Bras Med Trop 3: 53.

Pinto AFS, Vieira NER, Milanez MC, Lima Pereira FE, Sessa PA 1986. Doença de Chagas autóctone no Espírito Santo: relato de caso agudo em gestante com transmissão para o feto. Rev Soc Bras Med Trop 19 (Supl.): 78.

Santos UM, Pinto AFS, Zaganelli FL, Almeida AZ, Martins A, Carancho PV, Vieira HJ 1969a. Doença de Chagas no Estado do Espírito Santo. II - Inquérito sorológico. Rev Soc Bras Med Trop 3: 51.

Santos UM, Pinto AFS, Almeida AZ, Zaganelli FL, Carancho PV, Netto AN 1969b. Doença de Chagas no Estado do Espírito Santo. III - Vetores do tripanosoma. Rev Soc Bras Med Trop 3: 51-52.

Santos UM, Murad V, Chapadeiro E, Pereira Lima FE 1969c. Doença de Chagas no Estado do Espírito Santo. IV - Primeiro caso diagnosticado no município de Rio Nôvo do Sul. Rev Soc Bras Med Trop 3: 5253

Schofield CJ 1985. Population dynamics and control of Triatoma infestans. Ann Soc belge Méd trop 65:149164.

Schofield CJ, Lehane MJ, McEwan P, Catalá SS, Gorla DE 1991. Dispersive flight by Triatoma sordida. Trans $R$ Soc Trop Med Hyg 85: 676-678.

Schofield CJ, Lehane MJ, McEwan P, Catala SS, Gorla DE 1992. Dispersive flight by Triatoma infestans under natural climatic conditions in Argentina. Med Vet Entomol 6: 51-56.

Sessa PA, Carias VRD 1986. Infecção natural de triatomíneos do Espírito Santo por flagelados 
morfologicamente semelhantes ao Trypanosoma cruzi. Rev Soc Bras Med Trop 19: 99-100.

Silveira AC, Alencar TA, Máximo MH 1983. Sobre o Triatoma vitticeps Stal, 1859, no Espírito Santo, Brasil, 5-8. Resumos de Comunicações da X Reunião Anual de Pesquisa Básica em Doença de Chagas, Caxambu.

Silveira AC, Feitosa VR, Borges R 1984. Distribuição de triatomíneos capturados no ambiente domiciliar, no período de 1975/83, Brasil. Rev Brasil Malariol D Trop 36: 15-312.

Tonn RJ, Espínola H, Mora E, Jimenez JE 1978. Trampa de luz negra como método de captura nocturna de triatominos en Venezuela. Bol Dir Malariol San Amb 18: 25-30.

Zárate LG, Zárate RJ, Tempelis CH, Goldsmith RS 1980. The biology and behaviour of Triatoma barberi (Hemiptera: Reduviidae) in Mexico I. Blood meal sources and infection with Trypanosoma cruzi.JMed Entomol 2: 103-116.

Zeledón R 1983. Vectores de la enfermedad de Chagas y sus caracteristicas ecofisiologicas. Interciencia 8 : 384-395.

Zeledón R, Rabinovich JE 1981. Chagas' disease: an ecological appraisal with special emphasis on its insect vectors. Ann Rev Entomol 26: 101-133. 
718 Ecology of Triatoma vitticeps - Teresa CM Gonçalves et al. 